\title{
Nutritional and Anti-nutritional Analysis of Monechma ciliatum Leaves
}

\author{
Hassan, L. G. ${ }^{{ }^{*}}$, Msheila, H. E. ${ }^{2}$, Umar, K. J. ${ }^{3}$, Umar A. Umar ${ }^{4}$ and Onu, A. ${ }^{5}$ \\ 1'Department of Pure and Applied Chemistry, Usmanu Danfodiyo University, Sokoto, Nigeria. \\ 2Department of Pharmacognosy and Ethnopharmacy, Usmanu Danfodiyo University, Sokoto, Nigeria. \\ ${ }^{3}$ Department of Pure and Industrial Chemistry, Federal University Birnin Kebbi, Nigeria. \\ ${ }^{4}$ Department of Chemistry, Sokoto State University, Sokoto, Nigeria. \\ 5Department of Biochemistry, Usmanu Danfodiyo University, Sokoto, Nigeria. \\ *Corresponding author. Email: Ighassan2002@yahoo.com, hassan.lawal@udusok.edu.ng. Tel: 234-803-6076965.
}

Copyright (C) 2018 Hassan et al. This article remains permanently open access under the terms of the Creative Commons Attribution License 4.0, which permits unrestricted use, distribution, and reproduction in any medium, provided the original work is properly cited.

Received 24th March, 2018; Accepted 16th April, 2018

\begin{abstract}
Monechma ciliatum leaves are widely used as hay for animal nutrition and in traditional medicine for treatment of various ailments. The leaves were analyzed for proximate, minerals and anti-nutritional content using standard analytical methods. The results showed that the leaves contain moisture $(84.09 \pm 0.81 \%)$, ash $(14.00 \pm 0.50 \%)$, crude protein $(5.34 \pm 0.15 \%)$, crude lipid $(4.14 \pm 0.29 \%)$, crude fibre $(3.02 \pm 0.29 \%)$, available carbohydrate $(73.50 \pm 0.51 \%)$, and calorific value $(352.63 \pm 1.42 \mathrm{~kJ} / 100 \mathrm{~g})$. The mineral analysis of the leaves $(\mathrm{mg} / 100 \mathrm{~g})$ revealed the presence: sodium $(367.61 \pm 3.18 \mathrm{mg} / 100 \mathrm{~g})$, potassium $(931.59 \pm 10.70 \mathrm{mg} / 100 \mathrm{~g})$, magnesium $(213.77 \pm 2.31 \mathrm{mg} / 100 \mathrm{~g})$, calcium $(2444.60 \pm 43.70 \mathrm{mg} / 100 \mathrm{~g})$, phosphorus $(10.99 \pm 0.12 \mathrm{mg} / 100 \mathrm{~g})$, copper $(1.19 \pm 0.39 \mathrm{mg} / 100 \mathrm{~g})$, iron $(73.03 \pm 1.65 \mathrm{mg} / 100 \mathrm{~g})$, manganese $(5.33 \pm 0.25 \mathrm{mg} / 100 \mathrm{~g})$, zinc $(4.74 \pm 0.17 \mathrm{mg} / 100 \mathrm{~g})$, and chromium $(2.93 \pm 0.59 \mathrm{mg} / 100 \mathrm{~g})$. It also contains oxalate, tannins and phytic acid as anti-nutrients. The study showed that the leaves of $M$. ciliatum contain substantial levels of nutrient which could be useful in animal diet, with considerably low levels of anti-nutritional content which is below established toxic level.
\end{abstract}

Key words: Mineral contents, recommended dietary allowance, reference nutrient intake.

\section{INTRODUCTION}

The world is faced with problems of food scarcity, hunger and malnutrition for animal. This is due to increase in population, shortage of fertile land, high cost of available staples, and the policy constraints on feeds importation (Igbedioh, 1993; Haliru et al., 2017). In this perspective, animal nutrition is of considerable importance. The effectiveness by which the organism is able to transform feed biomass into edible animal products determines the total amount of feed which is necessary as well as the majority of emissions from animal production (Gerber et al., 2013; Brugger and Windisch, 2015).

Plants are generally accepted as good sources of nutrients and supplements for food as they are important sources of minerals, fibre and vitamins that provide essential nutrient for human and animals (Rathod and
Valvi, 2011). The role played by plants in human health and nutrition, food security and economic welfare of rural communities in developing world are of great importance. The availability of vegetables to some extent determines the importance of plants in human diets. The consumption of plants at various seasons is associated with potential health benefits (Isabelle et al., 2010).

Expansion of reasonably priced alternative sources of protein for humans and/or livestock might clearly reduce malnutrition. It may well be that such sources of protein will provide large quantities of animal feed ingredients if sufficient attention is given by researchers. The increase in feed results in high cost of edible of animal products as a result of competition between man and animals for feed or food stuff. The plant Monechma ciliatum (Plate 1) 
belongs to Acanthaceae family, and is distributed throughout tropical Africa as a wild and cultivated in Savanna. It is a small herb that grows a few inches above the ground, measuring about 4 to $7 \times 2 \mathrm{~cm}$. In Northern Nigeria, it is locally known as Damfarkami in Hausa language. It is characterized by long tap root and lanceolate leaves. It is commonly grazed by domestic animals especially sheep and goats. Animal keepers harvest them at the end of rainy season and store it as hay to be used during the dry season (Ogunsun et al., 2009). The seeds are used as an effective laxative (Mariod et al., 2009). The seeds of the plant contain hydrocarbons and fatty acids (Murtada and Abdelkarim, 2013). The seeds were found to contain fatty acids (palmitic, stearic, and linoleic), tocopherols, proteins, and elements (potassium, calcium, magnesium, aluminum, nickel, manganese, copper, chromium, cobalt, and iron) (Mariod et al., 2009).

Previous scientific studies have reported some phytoconstituents and antioxidant activities of the Monechma ciliatum. However, there are few scientific reports about the proximate, minerals and vitamins of this plant. This study therefore aimed at providing systematical importance on the nutritional and anti-nutritional content of M. cilatum leaves.

\section{MATERIALS AND METHODS}

\section{Sample collection and treatment}

The leaves of Monechma ciliatum were collected from the Sokoto State University, Sokoto, located at $12^{\circ} 56^{\prime} 38.38 \mathrm{~N}$ and 5011'15.30E (Figure 1) in the month of June, 2017. The sample was then transported to the laboratory in a paper envelope and identified at the herbarium of Botany Unit, Department of Biological Science, Usmanu Danfodiyo University, Sokoto. The voucher specimen with number UDOH/ANS/0191 was prepared and deposited for future reference at the herbarium of the department.

The samples of Monechma ciliatum leaves were air dried and pulverized using a wooden pestle and mortar. The powder was stored in an air tight container until it was needed for analyses.

\section{Proximate analysis}

The leaves were analyzed for proximate composition (moisture, ash, crude protein, lipid, available carbohydrate and crude fibre). The moisture content of the leaves was determined by oven drying to a constant weight at $105^{\circ} \mathrm{C}$. The ash content was determined by heating the leaves sample in a muffle furnace at $550^{\circ} \mathrm{C}$. Available carbohydrate was determined by difference. The lipid was extracted with n-hexane 60 to $70^{\circ} \mathrm{C}$ using soxhlet extractor for eight hours. The micro-Kjeldahl procedure was adopted for the determination of protein (AOAC, 1990).

\section{Determination of mineral contents}

The minerals were determined by atomic absorption photometry technique (Agomuo et al., 2016).

\section{Determination of potassium and sodium}

The ash of each sample obtained was diluted by adding 5 $\mathrm{cm}^{3}$ of $2 \mathrm{M} \mathrm{HCl}$ to the ash in the crucible and heat to dryness on a heating mantle. $5 \mathrm{~cm}^{3}$ of $2 \mathrm{M} \mathrm{HCl}$ was added again, heated to boil, and filtered with filter paper (Whatman No 1) into a $100 \mathrm{~cm}^{3}$ volumetric flask. The filtrate was made up to mark with distilled water and made ready for the reading of concentration of potassium and sodium on Jenway PFP7 Flame Photometer using the filter corresponding to each mineral element.

\section{Determination of $\mathrm{Ca}, \mathrm{Mg}, \mathrm{Cu}, \mathrm{Mn}, \mathrm{Fe}, \mathrm{Zn} \mathrm{Pb}$ and $\mathrm{Cr}$}

The digest of the ash was washed into $100 \mathrm{~cm}^{3}$ volumetric flask with distilled water and made up to mark. These diluents were aspirated into AA32ON Atomic Absorption Spectrophotometer (AAS) through the suction tube. Each of the trace mineral elements was read at their respective wavelengths with their respective hollow cathode lamps using appropriate fuel and oxidant combination.

\section{Determination of Phytate}

The standard method of Soetan (2012) was used. The $M$. ciliatum leaves sample $(4 \mathrm{~g})$ was soaked in $100 \mathrm{~cm}^{3}$ of $2 \%$ $\mathrm{HCl} v / \mathrm{v}$ for 3 hours and then filtered. To the $25 \mathrm{~cm}^{3}$ of the filtrate, $5 \mathrm{~cm}^{3}$ of $0.3 \% \mathrm{NH}_{4} \mathrm{SCN}$ and $53 \mathrm{~cm}^{3}$ of distilled water were added and mixed. The mixture was then titrated against $0.001 \mathrm{M}$ standard $\mathrm{FeCl}_{3}$ solution until a brownish yellow colour persists for 5 seconds. Phytin phosphorus ( $1 \mathrm{~cm}^{3}=1.19 \mathrm{mg}$ phytin phosphorus) was determined and the phytic acid content was calculated by multiplying the value of the phytin phosphorus by 3.55 .

\section{Determination of Oxalic acid}

Two grams of the $M$. ciliatum leaves sample was put into a $250 \mathrm{~cm}^{3}$ conical flask containing $190 \mathrm{~cm}^{3}$ of distilled water and $10 \mathrm{~cm}^{3}$ of $6 \mathrm{M} \mathrm{HCl} \mathrm{v/v}$. The mixture was diluted for 1 hour in a boiling water bath. After cooling, the mixture was then filtered. $50 \mathrm{~cm}^{3}$ aliquot of the sample was placed into a beaker and $20 \mathrm{~cm}^{3}$ of $6 \mathrm{M} \mathrm{HCl} \mathrm{v/v} \mathrm{was} \mathrm{added.} \mathrm{The}$ mixture was evaporated to about half of its volume and then filtered. The residue was washed several times with distilled water, and 3 drops of methyl orange indicator were added to $25 \mathrm{~cm}^{3}$ of the filtrate and titrated against $0.1 \mathrm{M}$ $\mathrm{KMnO}_{4} \mathrm{w} / \mathrm{v}$ solution till a faint pink colour appeared and 


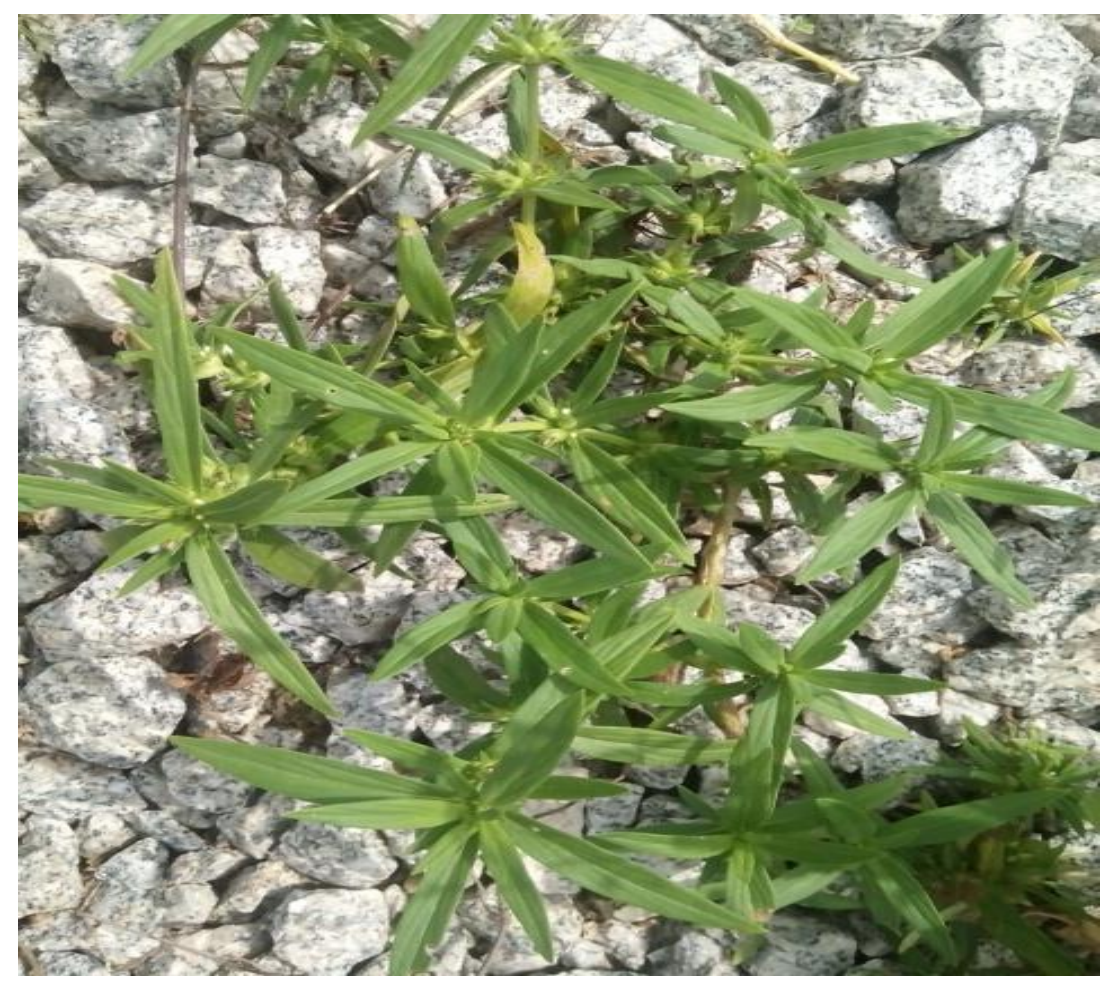

Plate 1. Photograph of Monechma ciliatum.

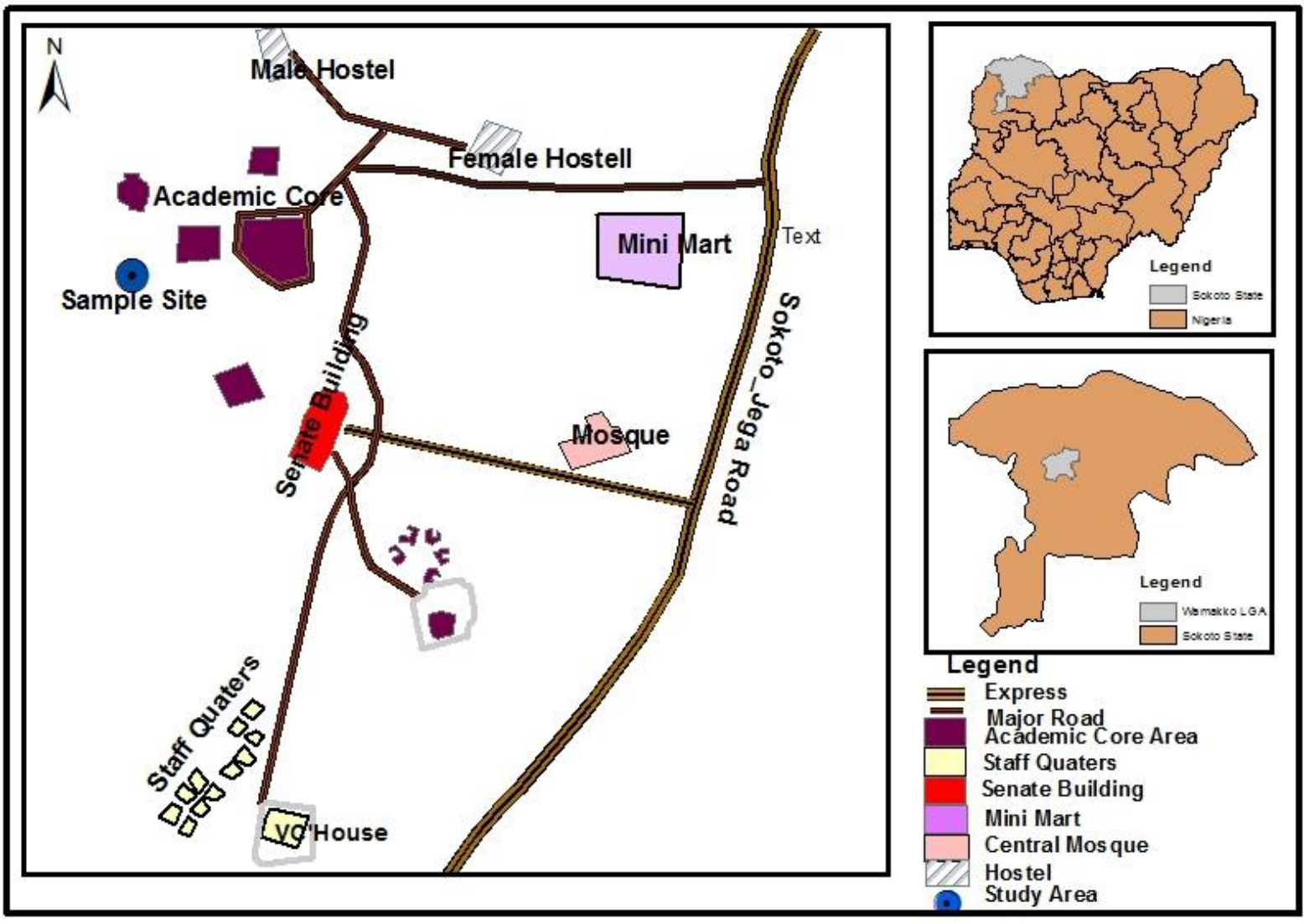

Figure 1. Map of sample site. 
Table 1. Proximate composition of Monechma ciliatum leaves.

\begin{tabular}{lc}
\hline Parameters & Concentration (\% Dry weight) \\
\hline Moisture & $84.09 \pm 0.81$ \\
Ash Content & $14.00 \pm 0.50$ \\
Crude Protein & $5.34 \pm 0.15$ \\
Crude lipid & $4.14 \pm 0.29$ \\
Crude Fibre & $3.02 \pm 0.29$ \\
Available Carbohydrate & $73.50 \pm 0.51$ \\
Energy Value (kJ/100 g DW) & $352.63 \pm 1.42$ \\
\hline
\end{tabular}

The data are mean value \pm standard deviation (SD) of three replicates.

persisted for 30 seconds (Day and Underwood, 1986).

Oxalate $(\mathrm{mg})=$ Titre Value $\mathrm{X} 0.0045$

\section{Determination of Hydrogen cyanide}

The alkaline titration procedure of Anhwange et al. (2006) was adopted. $10 \mathrm{~g}$ of the leaves sample was soaked in a mixture of $200 \mathrm{~cm}^{3}$ of distilled water and $10 \mathrm{~cm}^{3}$ of orthophosphoric acid. The mixture was left overnight to release all bounded hydrocynic acid. The mixture was distilled until $150 \mathrm{~cm}^{3}$ of the distillate was collected. $20 \mathrm{~cm}^{3}$ of distilled water, $8 \mathrm{~cm}^{3}$ of $6 \mathrm{M}$ aqueous ammonia and 2 $\mathrm{cm}^{3}$ of $5 \%$ potassium iodide solution were added and then titrated with $0.02 \mathrm{M}$ silver nitrate to taint, but permanent turbidity.

\section{Determination of Tannins}

Tannins were determined by the vanillin- $\mathrm{HCl}$ procedure, which was base on acid catalyzed addition of vanillin to flavonols. These reactions are determined calorimetrically at $500 \mathrm{~nm}$ (Anhwange et al., 2006).

\section{Determination of Nitrate}

The method described by IITA (1988) was adopted in which $100 \mathrm{mg}$ of the powdered sample were weighed into a $15 \mathrm{~cm}^{3}$ centrifuge tube, and $10 \mathrm{~cm}^{3}$ of distilled water were added. The content was incubated in water bath at $45^{\circ} \mathrm{C}$ for one hour, cooled and centrifuged at 5000 revolutions per minute for 15 minutes. The clear supernatant was put into a clean test tube, stoppered and stored in a refrigerator prior to nitrate analysis.

Nitrate stock solution (100 ppm) was prepared by dissolving $\mathrm{KNO}_{3}(1.63 \mathrm{~g})$ in distilled water in a $100 \mathrm{~cm}^{3}$ volumetric flask up to the mark. To prepare series of standard solutions of $0,1,2,3,4$ and $5 \mathrm{ppm}, 0,0.2,0.4$, $0.6,0.8$ and $1.0 \mathrm{~cm}^{3}$ of the stock solution were added to six $20 \mathrm{~cm}^{3}$ volumetric flask. Similarly, $0.2 \mathrm{~cm}^{3}$ of the extract was put into another $20 \mathrm{~cm}^{3}$ volumetric flask. In the flasks, $0.8 \mathrm{~cm}^{3}$ of $5 \%(\mathrm{w} / \mathrm{v})$ salicylic acid-sulphuric acid reagent was added and mixed thoroughly. The content was allowed to stand for 20 minutes and followed by the addition of $2 \mathrm{M} \mathrm{NaOH}$ solution (to raise the $\mathrm{pH}$ to above 12) to the mark. The content was cooled to room temperature and its absorbance measured at $410 \mathrm{~nm}$ with a spectrophotometer. The calibration curve was plotted from which the concentration of nitrate $(X)$ in the samples was extrapolated and nitrate content in the sample was calculated using the equation below.

$\mathrm{NO}_{3}\left(\frac{\mathrm{mg}}{100 \mathrm{~g}}\right)=\frac{\mathrm{X}(\mathrm{ppm}) \mathrm{X} \text { solution volume }\left(\mathrm{cm}^{3}\right)}{\text { Aliquot }\left(\mathrm{cm}^{3}\right) \mathrm{X} \text { sample weight }(\mathrm{g})} \times 100$

\section{Data analysis}

Data generated were expressed as the mean of standard deviation in triplicates.

\section{RESULTS AND DISCUSSION}

\section{Proximate composition}

The proximate analysis of the leaves indicated an appreciable amount of moisture content (Table 1) which was high compared to Ocimum gratissimum leaves (Idris et al., 2011), and was lower than Ipomoea batatas (L) leaves (88.43\%) (Sun et al., 2014). The result showed that M. ciliatum leaves contain high ash content $(14.00 \%$ DW). The value was higher than what was obtained from its seeds $(4.00 \%$ DW) as reported by Hassan et al. (2007a). This value was higher than the ash content of Mucuna pruriens $(7.80 \% \mathrm{DW})$ as reported by Enemchukhu et al. (2015). The high values of ash content may indicate that the leaves contain some nutritionally essential minerals essential for growth and development of livestock. Therefore, dried leaves could be used as animal feed to supplement some vital mineral elements (Suleiman, 2016).

Monechma ciliatum leaves had $5.34 \%$ protein and 
Table 2. Elemental analysis of Monechma ciliatum leaves.

\begin{tabular}{lcc}
\hline Mineral Element & $\begin{array}{c}\text { Concentration } \\
\text { [mg/100g dry weight] }\end{array}$ & $\begin{array}{c}\text { RDA Value for Goat } \\
\text { [mg/100g dry matter] }\end{array}$ \\
\hline $\mathrm{K}$ & $931.59 \pm 10.70$ & 220 \\
$\mathrm{Na}$ & $367.61 \pm 3.18$ & 70 \\
$\mathrm{Ca}$ & $2444.70 \pm 43.70$ & 260 \\
$\mathrm{Mg}$ & $213.77 \pm 2.31$ & 170 \\
$\mathrm{P}$ & $10.99 \pm 0.12$ & 270 \\
$\mathrm{Cu}$ & $1.19 \pm 0.39$ & 0.9 \\
$\mathrm{Fe}$ & $73.03 \pm 1.65$ & 3.5 \\
$\mathrm{Mn}$ & $5.33 \pm 0.25$ & 3 \\
$\mathrm{Zn}$ & $4.74 \pm 0.17$ & 3 \\
$\mathrm{Cr}$ & $2.93 \pm 0.59$ & \\
$\mathrm{~Pb}$ & $\mathrm{ND}$ & \\
\hline
\end{tabular}

The data is mean value \pm standard deviation (SD) of three replicated. ND $=$ Not Detected.

$73.50 \%$ available carbohydrate. This crude protein content was higher than the values reported for Ipomoea batatas leaves (6.37\%) dry weight (Ahmed, 2014). The leaves had a high level of available carbohydrate. Similar to crude protein, $M$. ciliatum leaves had high content of carbohydrate comparable to $51.80 \%$ in Moringa stenopetala leaves (Abuye et al., 2003) and 16.50\% (dry weight) found in T. Cucumerina (Ugbaja et al., 2017), and was also higher than the value of $70.55 \%$ (dry weight) of Monechma ciliatum seeds (Hassan et al., 2007a). Carbohydrate serves as stored forms of energy as glycogen in the liver. It also provides a primary source of energy (Hassan and Umar, 2006).

When compared to tropical grasses, legumes have lower fibre content and a higher level of crude protein (Lopes et al., 2017). Therefore, legumes are considered forages with high nutritional value. $M$. ciliatum is high in energy, crude protein, calcium, and potassium, in addition to improved palatability and digestibility, which allows for more significant intake potential (Juliatti et al., 2011).

The crude lipid content was low (4.14\%) when compared with the value reported for its seeds (Hassan et al., 2007b), and also similar to that of Aloe vera (4.2\%) and Euphorbia radians (4.9\%) (Sotelo et al., 2007). Also, the leaves of Monechma ciliatum had a low level of crude fibre (3.02\%) when compared with the leaves of Ipomoea batatas (12.67\%) and Gnetum africanum (4.6\%) (Ahmed, 2014). Fibre plays a role in the prevention of diseases by reducing the level of cholesterol, high blood pressure and constipation (Hassan et al., 2011). Thus, Monechma ciliatum leaves could be valuable sources of dietary fibre.

The calorific value of $M$. ciliatum leaves is 352.63 $\mathrm{kJ} / 100 \mathrm{~g}(\mathrm{DW})$, which is high compared to the 248.8 to $307.1 \mathrm{~kJ} / 100 \mathrm{~g}$ reported for some Nigerian leafy vegetables (Hassan and Umar, 2006). However, M. Ciliatum leaves had lower calorific value when compared with the leaf of Mucuna pruriens (Enemchukwu et al., 2015). The results showed that $M$. ciliatum leaves could serve as an alternative supplement of feed for animals which will reduce the cost of animal feed, thereby resulting in significant economic return.

\section{Determination of mineral components of Monechma ciliatum leaves}

The mineral analysis of $M$. ciliatum leaves is presented in Table 2. From the result, the leaves had a high concentration of calcium, potassium, sodium and magnesium; while it showed lower concentration of phosphorus and chromium.

Potassium is a primary electrolyte and a major cation inside the cell; and low potassium in the blood is a lifethreatening problem (Allen, 2003). Potassium is very vital in regulation of water and electrolyte balance and acidbase balance in the body, as well as responsible for nerve action and functioning of the muscles. The potassium content was $931.59 \pm 10.70 \mathrm{mg} / 100 \mathrm{~g}$ (Table 2). Although, this is low as compared with $3283.00 \pm 7.60$ of Pistia stratiotes as reported by Wasagu et al. (2013). It is sufficiently adequate compared to the recommended quantity for lactating goats (NRC, 1974) and has the potential of meeting this requirement with increased consumption of the quantity of the plants daily. Therefore, M. ciliatum could serve as good source of potassium. The sodium content was $367.61 \pm 3.18 \mathrm{mg} / 100 \mathrm{~g}$. This study showed that the leaves of $M$. ciliatum are high in sodium as compared to the Recommended Daily Allowance of 70 $\mathrm{mg} / 100 \mathrm{~g}$ for a goat (Hassan et al., 2007a).

Calcium is an essential component of a healthy diet and a mineral necessary for life. It plays a vital role in building healthy and dense bones and teeth, blood clotting and for normal functioning of the heart, nervous system and muscles (Idris et al., 2011). The value obtained for calcium was $2444.70 \pm 43.70 \mathrm{mg} / 100 \mathrm{~g}$. The report of this findings showed that the value obtained for calcium was much 
higher than that of Momordica balsamina leaves (941.00 $\mathrm{mg} / 100 \mathrm{~g}$ ) but lower than the value of $3512.60 \mathrm{mg} / 100 \mathrm{~g}$ dried leaves of Moringa oleifera (Charles et al., 2011). Hence, it is high enough to meet the requirement and could therefore be regarded as a good source of calcium. The availability of calcium in body fluids and water showed that it is water soluble (Lean, 2006).

Phosphorus level found in $M$. ciliatum leaves was $10.99 \pm 0.12 \mathrm{mg} / 100 \mathrm{~g}$. The value was higher than that of Senna alata $(0.47 \pm 0.02 \mathrm{mg} / 100 \mathrm{~g})$ (Adigun, 2014). The value was also higher than $(0.07 \mathrm{mg} / 100 \mathrm{~g})$ recorded in Andropogon gayanus (Ajiji et al., 2013). This showed that $M$. ciliatum is a good source of phosphorus. The copper content was found to be $1.19 \pm 0.39 \mathrm{mg} / 100 \mathrm{~g}$. This showed that the copper content of Monechma ciliatum is slightly higher as compared to the recommended dietary allowance (Hassan et al., 2007a). Therefore, the plant is needed to enable the absorption and mobilization of iron and its utilization in haemoglobin synthesis. The concentration of iron in the leaves was found to be $73.03 \pm 1.65 \mathrm{mg} / 100 \mathrm{~g}$ which indicated that it is a good source of iron compared to the recommended daily requirement of iron for goat which is $3.50 \mathrm{mg} / 100 \mathrm{~g}$ (Hassan et al., 2007a). Iron is essential in the formation of haemoglobin in red blood cells and its deficiency leads to anaemia. $M$. ciliatum could be used to improve the anaemic condition of a goat.

Manganese is a metallo-enzyme involved in pyruvate metabolism and also required for glucose exploitation. Dietary manganese deficiencies in domestic animals are less common than deficiency of copper or chromium. Signs include poor growth and skeletal deformities in newborn calves and reproductive abnormalities, including anestrus in adult cows (Thomas, 2016). The value of manganese obtained $(5.33 \pm 0.25 \mathrm{mg} / 100 \mathrm{~g})$ was slightly higher than that of Vernonia amygdalina (Agomuo et al., 2016). Thus, adequate consumption would meet the needs, since adequate intake of manganese is 2.3 $\mathrm{mg} /$ day.

The zinc content was $4.74 \pm 0.17 \mathrm{mg} / 100 \mathrm{~g}$. Lean (2006) stated a reference nutrient intake of $9 \mathrm{mg}$ of $\mathrm{Zn} /$ day. Zinc is essential for the activation of specific enzymes. Zinc containing organic compounds is employed as astringent and anti-fungal agents. It aids wound healing and metabolism of nucleic acid and insulin (Sharma et al., 2012). Zinc deficiency in developing countries is becoming a growing concern because it has been shown that zinc deficiency is related not only to decrease growth, but also to increase morbidity and impaired immune function (Agomuo et al., 2016). There is clear evidence for livestock nutrition as a major promoter of zinc and copper accumulation in agricultural areas (Wuana and Okieimen, 2011). Therefore, high zinc and copper doses potentially express the bactericidal effect in the soil. A proper functioning soil microbiome is inevitable for normal plant development. Hence, toxic overload of zinc and copper in soil impairs plant production (Rout and Das, 2003).
Table 3. Anti-nutritional factors of Monechma ciliatum leaves.

\begin{tabular}{lc}
\hline Parameters & Composition $(\mathbf{m g} / \mathbf{1 0 0} \mathbf{g ~ D W})$ \\
\hline Oxalate & $0.0009 \pm 0.0000$ \\
Phytate & $13.0960 \pm 0.0001$ \\
Nitrite & $1.6367 \pm 0.0577$ \\
Cyanide & $0.0827 \pm 0.0006$ \\
Tannins & $0.0357 \pm 0.0006$ \\
\hline
\end{tabular}

The values are mean \pm standard deviation of three replicates.

Table 4. Anti-nutrient to Nutrient Molar Ratio of Monechma ciliatum leaves.

\begin{tabular}{lc}
\hline Anti-nutrient to nutrient & Molar Ratio \\
\hline [Oxalate]/[Ca] & $1.66 \times 10^{-7}$ \\
[Oxalate]/[Ca+Mg] & $1.45 \times 10^{-7}$ \\
[Phytate]/[Ca] & $3.25 \times 10^{-4}$ \\
[Phytate]/[Fe] & 0.02 \\
[Phytate]/[Zn] & 0.27 \\
[Ca][Phytate]/[Zn] & 0.17 \\
\hline
\end{tabular}

The result of the anti-nutritive composition of $M$. ciliatum leaves is presented in Table 3. From the result, the leaves had a lower level at anti-nutritive content for which phytate bring the highest.

The anti-nutritional factor in the leaves of $M$. ciliatum leaves was below toxic levels and so does not front many adverse effects on patrons. The anti-nutritional was phytate, oxalate, nitrite and cyanide (Table 4). The phytate content of $M$. ciliatum leaves $(13.0960 \pm 0.0001 \mathrm{mg} / 100 \mathrm{~g})$ is lower than raw and higher in blanched Colocasia esculenta leaves (27.0 and $12.0 \mathrm{mg} / 100 \mathrm{~g} \mathrm{DW}$ ) (Odedeji et al., 2014). The phytate in food can bind some essential mineral elements such as $\mathrm{Ca}, \mathrm{Mg}, \mathrm{Zn}$ and $\mathrm{Fe}$ in the digestive tract and render them not bio-available. Protein and starch solubility digestion was also reported to be affected by phytate (Bello, 2008). Nevertheless, phytate is a potent anti-carcinogen that protects against colon cancer. It is also known to be a potent antioxidant that inhibits Fenton reactions leading to lipid peroxidation and inhibition of polyphenol oxidase (Agte et al., 1999).

The concentration of oxalate in $M$. ciliatum is $0.0009 \pm 0.0000 \mathrm{mg} / 100 \mathrm{~g}$ dry weight. The value is lower when compared with that of Moringa oleifera leaves $(0.87 \pm 0.02 \%)$ (Kehinde and Olapeju, 2016). On the other hand, oxalate in $M$. ciliatum was higher than $585.00 \pm 18.63$ $\mathrm{mg} / 100 \mathrm{~g}$ recorded for Melocia corchorifolia leaves (Hassan et al., 2011). High oxalate content causes irritation in the mouth and interferes with the absorption of divalent minerals particularly calcium by forming insoluble salts with them leading to kidney stone which may eventually lead to death (Jimam et al., 2013). The concentration of nitrate in the sample $(1.6367 \pm 0.0577$ $\mathrm{mg} / 100 \mathrm{~g}$ dry weight) was below the acceptable daily intake 
of $3.7 \mathrm{mg} / 100 \mathrm{~kg}$ body weight equivalent to $220 \mathrm{mg}$ for 60 $\mathrm{kg}$. The nitrate concentration is also lower compared to Melocia corchorifolia leaves $(74.41 \pm 1.16 \mathrm{mg} / 100 \mathrm{~g})$ reported by Hassan et al. (2011). Furthermore, boiling was reported to reduce nitrate to about 60 to $70 \%$ as observed in plants (Hassan and Umar, 2014). Studies have indicated that nitrates generally causes methaemoglobinaemia in infants, but not in adults (Hassan et al., 2011). However, when reduced to nitric oxide, it plays a vital role in the body as it provides host defense against numerous micro-organisms (Benjamin, 2009). The hydrogen cyanide content was $0.0827 \pm 0.0006 \mathrm{mg} / 100 \mathrm{~g}$ $\mathrm{DW}$. The value is lower compared to the value obtained for Hibiscus sabdariffa $(0.29 \mathrm{mg} / 100 \mathrm{~g} \mathrm{DW}$ ) (Anhwange et al., 2006). Anhwange et al. (2006) reported that high hydrogen cyanide content in the diet causes neurological, respiratory, cardiovascular and thyroid debilities. Low hydrogen cyanide content of the leaves is an indication that it can be used in formulation of animal feeds. The concentration of tannins in $M$. ciliatum leaves was $0.0357 \pm 0.0006 \mathrm{mg} / 100 \mathrm{~g}$ dry weight. The value is similar to that of Moringa oleifera leaves $(0.05 \pm 0.01 \mathrm{mg} / 100 \mathrm{~g})$ (Kehinde and Olapeju, 2016). The nutritional effect of tannins is mainly related to their interaction with protein (Kehinde and Olapeju, 2016). Tannins are known to inhibit the activities of enzymes such as trypsin, chemotrypsin, amylase and lipase and also interfere with iron absorption and growth in general (Umar et al., 2007; Hassan et al., 2007b).

To appraise the bioavailability of some mineral elements specifically $\mathrm{Ca}, \mathrm{Mg}, \mathrm{Fe}$, and $\mathrm{Zn}$, the anti-nutrients to nutrients molar ratios were calculated, and the result presented in Table 4. It was observed that, [Oxalate]/[Ca], [Oxalate]/[Ca $+\mathrm{Mg}]$ and $[\mathrm{Ca}][$ Phytate]/[Zn] ratio are all below the critical level known to impair calcium and magnesium bioavailability (Hassan et al., 2008). Even though it was reported that $\mathrm{Zn}$ is the most affected by phytate in animals, [Phytate]/[Zn] ratio was below the significant level to interfere with zinc bioavailability (Hassan et al., 2008). Therefore, it is expected to use mineral elements supplements in practical feeding.

\section{Conclusion}

This work revealed that Monechma ciliatum leaves contain an appreciable amount of carbohydrate, ash, crude fibre, crude protein, crude lipid and minerals. The leaves also contain substantial amount of nutrients with low levels of anti-nutritional content such as oxalate, phytate, nitrite, cyanide and tannins which were below established toxic levels. The plant leaves could serve as an alternative source of energy.

\section{CONFLICT OF INTEREST}

The authors declare that they have no conflict of interest.

\section{REFERENCES}

Abuye, C., Urga, K., Knapp, H., Selmar, D., Omwega, A. M., Imungi, J. K., \& Winterhalter, P. (2003). A Compositional Study of Moringa stenopetala Leaves. East African Med. Journal, 80, 247-252.

Adigun, R. A. (2014). Antimicrobial and proximate analysis of Senna alata seed MSc. Dissertation, Postgraduate School, Usmanu Danfodiyo University, Sokoto.

Agomuo, J. K., Akajiaku, L. O., Alaka, I. C., \& Taiwo, M. (2016). Mineral and Antinutrients of Fresh and squeezed-washed bitter leaf (Vernonia amygdalina) as affected by traditional debittering methods. European Journal of Food Science and Technology, 4(2), 21-30.

Agte, V. V., Tarwadi, K. V., \&Chiplonkar, S. A. (1999). Phytate degredation during traditional cooking: significance of the phytic acid profile in cereal-based vegetarian meals. Journals of Food Composition and Analysis, 12, 161-167.

Ahmed, A. (2014). Phytochemical Screening, Proximate and Mineral Composition of Sweet Potato Leaves Grown in Tepi Provision, South- West of Ethiopia. Science, Technology and Arts Research Journal, 3(3), 112-115.

Ajiii, I., Nyako, H. D., \& Ashom, S. A. (2013). Performance of yankasa rams fed with Andropogon gayanus (Gamba grass) hay supplemented with Faidherbia albida (Acacia) Pods. Journal of Biology, Agriculture and Healthcare, 3(13), 67-69.

Allen, L. H. (2003). Intervention for micronutrient deficiency control in developing countries: past, present and future. Journal of Nutrition, 133, 3875-3878.

Anhwange, B. A., Ajibola, V. O., \& Okibe, F. G. (2006). Nutritive Value and Anti-nutritional Factors in Hibiscus sabdariffa. Journal of fisheries international, 1(2-4), 73-76.

AOAC (1990). Official methods of Analysis, $4^{\text {th }}$ edition, Association of Analytical Chemists, Washington DC.

Banwat, S. B., Dafam, D. G., \& Tochukwu, E. (2013). Nutritional and antinutritional analysis of Chrysanthellum indicum leaves. The Journal of Phytopharmacology, 2(6), 26-30.

Bello, M. O., Farade, O. S., Adewusi, S. R. A., \& Olawore, N. O. (2008). Studies of some lesser known Nigerian fruits. African Journal of Biotechnology, 7(1), 3972-3979.

Benjamin C. J. (2009). Guide to Nutritional Supplements, $2^{\text {nd }}$ edition. Oxford. UK. ISBN 978-0-12-375109-6.

Brugger, D., \& Wilhelm, M. W. (2015). Environmental responsibilities of livestock feeding using trace mineral supplements: Review. Animal Nutrition, 1, 113-118.

Charles, A. N., Marcel, D. B., Aly, S., Philippe, A. N., \& Sabadenedyo, A. T. (2011). Determination of Chemical Composition and Nutritional Value of Moringa oleifera leaves. Pakistan Journal of Nutrition, 10(3), 364-268.

Day, R. A., \& Underwood, A. L. (1986). Quantitative analysis. $5^{\text {th }}$ edition. Parentice- Hall publication. London, U. K. p. 701.

D'Mello, J. P. F. (2000). Anti-nutritional factors and mycotoxins. In: Farm animal metabolism and nutrition. $C A B$ International Wallingford, UK. Pp. 383-403.

Enemchukhu, B. N., Uchenna N., Udedi S. C., \& Akalonu, X. C. (2015). Nutritional and Anti-Nutritional Evaluation and Phytochemical Composition of Aqueous Leaf of Mucuna pruriens. The Bioscientist Journal. 3(1), 93-100.

Gerber, P. J., Steinfeld, H., Henderson, B., Mottet, A., Opio, C., Dijkman, J., Falcucci, A., \& Tempio, G. (2013). Climate change through livestock- a global assessment of emissions and mitigation. Rome (Italy): Food and Agricultural organization of the united nations (FAO).

Haliru, M. E., Abiodun, D. J., Hassan, L. G., Umar, K. J., 
Res. J. Food Sci. Nutr.

Maishanu, H. M., \& Warra. A. A. (2017). Proximate and mineral composition of Ipomoea carnea seeds. Journal of Chemical Society of Nigeria, 42(2), 11-14.

Hassan, L. G., \& Umar, k. J. (2006). Nutritional Value of Balsam apple (Momordica balsa mina L.) Leaves. Pakistan Journal of Nutrition. 5(6), 522-529.

Hassan, L. G., Bagudo, B. U., Aleiro, A. A., Umar, K. J., \& Sani, N. A. (2007b). Evaluation of Nutritient and Anti-nutrient Content of Pakia biglobosa (L.) Flower. Ngerian Journal of Basic and Applied Science. 19(1), 76-80.

Hassan, L. G., Umar, K. J. \& Tijjani, A. A. (2007a). Preliminary Investigation on the Feed Quality of Monechma ciliatum Seeds. Chemclass Journal. CSN Zaria. Pp. 83-86.

Hassan, L. G., Dangoggo, S. M., Umar, K. J., Saidu, I., \& Folorunsho, F. A. (2008). Proximate, Minerals and Antinutritional factors of Daniellia oliveri Seed kernel. Chem. Class Journal, 5, 31-36.

Hassan, L. G., Umar, K. J., Dangoggo, S. M., \& Maigandi, A. S. (2011). Anti-nutrient Composition and Bioavailability Prediction as Exemplified by Calcium, Iron and Zinc in Melocia corchorifolia Leaves. Pakistan Journal of Nutrition, 10(1), 2328.

Idris, S., lyaka, Y. A., Ndamitso, M. M., \& Paiko, Y. B. (2011). Nutritional Composition of the Leaves and Steams of Ocinum gratissium. Journal of Emerging Trends in Engineering and Applied Sciences, 2(5), 801-805.

Igbedioh, S. O. (1993). Under-nutrition in Nigeria: dimensions, causes and remedies for alleviation in a changing socio-economic environment. Nutrition and Health, 9, 1-4.

Isabelle, M., Lee, B. L., Lim, M. T., Koh, W. P., Huang, D., \& Ong, C. N. (2010). Anti-oxidant activity and profiles off common fruits in Sigapore. Food Chemistry, 123, 77-84.

Jimam, N. S., Banwat, S. B., Damfam, D. G., \& Tochukbvu, E. (2013). Nutritional and Antiinutritional Analysis of Chrysanthellum indicum leaves. The Journal of Phytopharmacology. 2(6), 26-30.

Juliatti, F. C., Pimenta, F. A., Martins, J. A. S., Pozza, E. A., Silva, S. D. A. D., Rey, M. D. S., \& Santos, R. R. D. (2011). Resistance alfalfa cultivars to Antracnosis and Leptosphaerulina leaf spot in Uberlandia-MG. Summa Phytopathol., 37, 169-173.

Kehinde, O. S., \& Olapeju, O. A. (2016). Proximate Analysis, Minerals and Anti-nutritional Factor of Moringa oleifera Leaves. Annals of Food Science and Technology, 17(1), 253-256.

Lean, M. N. (2006). Vitamins and other bioactive food constituents in Food Science, Nutrition and Health (7th edition). Edward Hodder Ltd, London. Pp. 198-216.

Lopes, L. A., Carvalho, F. F. R., Cabral, A. M. D., Batista, A. M. V., Camargo, K. S., Silva, J. R. C., Ferreira, J. C. S., Pereira Neto, J. D., \& Silva, J. L. (2017). Replacement of tifton hay with alfalfa hay in spineless cactus-based diets for dairy goats. Small Ruminant Research, 156, 7-11.

Mariod, A. A, Aseel, K. M, Mustafa, A. A., \& Ibrahim, S. (2009). Characterization of the Seed Oil and meal from Monechma ciliatum and Prunus mahaleb Seeds. Journal of the American Oil Chemists' Society, 86(8), 749-755.

Murtada, A. O., \& Abdelkarim, M. A. (2013). Phytochemical screening and evaluation of Monechma ciliatum (black mahlab) seed extracts as antimicrobial agents. Avicenna Journal of Phytomedicine, 3(2),126-134.

NRC (National Research Council) (1974). Recommended daily allowances, united states food and nutrition board, national academy of science. Washington D.C. USA. Pp. 67-68.
Odedeji, J. O., Oyeleke, G. O., Ayinde, L. A., \& Azeez, L. A. (2014). Nutritional, Antinutitional Compositions and Organoleptic Analysis of Raw and Blanched Cocoyam (Colocasia esculenta). Journal of Environmental Science, Toxicology and Food Technology, 8(2), 45-48.

Ogunsun, E. A, Ipinjolu, J. K., Dneji, A. I., Ehizibola, D.O., Junaidu A. U., Chafe, U. M., \& Tambuwal, F. M. (2009). Effects of feeding different levels of Monechma ciliatumon the Performance of rabbit in Sokoto Nigeria. Research Journal of Animal Sciences, 4(5), 121-124.

Rathod, V. S., \& Valvi, S. G. (2011). Mineral Compositionof some Wild edible Fruits from Kolhapur District. Journal of Applied Biology and Pharmaceutical Technology, 2, 392-396.

Rout, G. R., \& Das, P. (2003). Effect of metal toxicity on plant growth and metabolism: I. Zinc. Agronomie, 23, 3-11

Sharma, N., Gupta, P. C., \& Rao, C. V. (2012). Nutrient content, mineral content and antioxidant activity of Amaranthus viridis and Moringa oleifera leaves. Research Journal of Medicinal Plants, 6(3), 253-259.

Soetan K. O. (2012) Comparative Evaluation of Phytochemicals in the raw and aqueous crude extracts from seeds of three Lablab purpureus varieties. African Journal of Plant Science, 6(15), 410-415.

Sotelo, M., Andrade, J. M., Carlosena, A., \& Tauler, R. (2007). Temporal in urban and semi-urban areas using physicochemical parameters and chemometric methods. Anal Chim. Acta., 583, 128-137.

Suleiman, M. (2016). Nutritional and Anti-nutritional Composition of Pennisetum Pedicellatum Trin. Grass. MSc. Dissertation, Postgraduate School, Usmanu Danfodiyo University, Sokoto.

Sun, H., Taihua, M., Lisha, X., Miao, Z., \& Jingwan, C. (2014). Sweet potato (Ipomoea batatas L.) leaves as nutritional and fuctional foods. Food chemistry, 156 380-389.

Thomas, H. H. (2016). Nutritional requirements of dairy cattle veterinary manual. Merck sharp and Dohme corp., a subsidiary of merck and co., inc., Kenilworth, NJ, USA.

Ugbaja, C. C., Fawibe, O. O., Oyelakin, A. S., Fadimu, I. O., Ajiboye, A. A., \& Agboola, D. A. (2017). Comparative Phytochemical and Nutritional Composition of Trichosanthes cucumerina (L.) and Some Solanum lycopersicum (L.) Cultivars in Nigeria. American Journal of Plant Sciences, 8, 297-309.

Umar, K. J., Hassan, L. G., Dangoggo, S. M., \& Ladan, M. J. (2007). Nutritional composition of water spinach (Ipomoea aquatica Forsk.) leaves. Journal of Applied Sciences, 7(6), 803-809.

Wasagu, R. S. U., Lawal, M., Shehu, S. Alfa, H. H., \& Muhammad, C. (2013). Nutritive Values, Mineral and Antioxidant properties of Pistia stratiotes (Water lettuce). Nigerian Journal of Basic and Applied Science. 21(4), 253-257.

Wuana, R. A., \& Okieimen, F. E. (2011). Heavy metals in contaminated soils: a review of sources, chemistry, risks and best available strategies for remediation. International Scholarly Research Network ISRN Ecology, 2011, Article ID 402647, 20 pages. 